Tersedia online di: http://ejournal-balitbang.kkp.go.id/index.php/bawal
e-mail:bawal.puslitbangkan@gmail.com
BAWAL wIDYA RISET PERIKANAN TANGKAP
Volume 8 Nomor 3 Desember 2016
p-ISSN: 1907-8226
e-ISSN: 2502-6410
BAWAL
Nomor Akreditasi: $620 /$ AU2/P2MI-LIPI/03/2015

\title{
BEBERAPA ASPEK BIOLOGI IKAN TENGGIRI PAPAN (Scomberomorus guttatus) DI PERAIRAN CILACAPDAN SEKITARNYA
}

\section{BIOLOGICAL ASPECTS OF INDO-PACIFIC KING MACKEREL (Scomberomorus guttatus) IN CILACAP AND ADJACENT WATERS}

\author{
Yoke Hany Restiangsih*, Tegoeh Noegroho dan Karsono Wagiyo \\ Balai Penelitian Perikanan Laut, Jl. Muara Baru-Jakarta Utara-14430, Indonesia \\ Teregistrasi I tanggal: 25 Nopember 2016; Diterima setelah perbaikan tanggal: 20 Desember 2016; \\ Disetujui terbit tanggal: 22 Desember 2016
}

\begin{abstract}
ABSTRAK
Tenggiri papan (Scomberomorus guttatus) merupakan ikan yang memiliki nilai ekonomis penting dan banyak tertangkap dengan gillnet di perairan Cilacap dan sekitarnya. Pada saat ini terdapat kecenderungan ukuran individu yang mengecil. Tujuan Penelitian ini adalah mengetahui beberapa aspek biologi ikan tenggiri papan meliputi sebaran ukuran panjang, hubungan panjang-bobot, nisbah kelamin, tingkat kematangan gonad dan ukuran rata-rata pertama kali matang gonad, berdasarkan hasil tangkapan gillnet yang didaratkan di Pelabuhan Perikanan Samudera Cilacap pada bulan Februari sampai Desember 2013. Hasil penelitian menunjukkan ukuran panjang cagak berkisar antara $11-67 \mathrm{~cm}$. Pola pertumbuhan ikan tenggiri papan bersifat isometric dimana pertambahan panjang dan bobotnya seimbang. Nisbah kelamin jantan terhadap betina sebagai $1: 0,7$. Panjang pertama kali ikan tertangkap (Lc) dengan gillnet berukuran mata jaring 3 inchi sebesar 32,7 cmFL dan pertama kali matang gonad (Lm) sebesar 42,34 cmFL. Tingkat Kematangan Gonad (TKG) ikan jantan dan betina didominasi oleh stadia IV terutama pada bulan Februari dan Mei. Hasil penelitian ini menunjukkan dugaan awal masa pemijahan terjadi pada bulan Maret dan Juni, dengan demikian pemijahan dilakukan secara bertahap.
\end{abstract}

Kata Kunci: Biologi; Scomberomorus guttatus; Cilacap

\section{ABSTRACT}

Indo-Pasific king mackerel (Scomberomorus guttatus) is one of fish that has an important economic value.The species were many caught by gillnet in Cilacap and adjacent waters. Research was conducted to determine biological aspect of Indo-Pasific king mackerel that includes length distribution, length-weight relationship, sex ratio, maturity stage and length at first mature, based on monthly catches landed at Cilacap fishing port during February to December 2013. The results showed that folk length ranged from 11 to $67 \mathrm{~cm}$. The growth pattern are isometric. The condition of sex ratio of males to females was 1:0,7. Length at first capture $(L c)$ by gillnet with mesh size of 3 inches was $32.7 \mathrm{cmFL}$ and length at first maturity $(\mathrm{Lm})$ was $42.34 \mathrm{cmFL}$. The gonade maturity stage of males and females were dominated by stage IV mainly in Febuary and May. It was indicated that spawning seasons occured in March and June. It was indicated that the fish has multiple spawner.

Keywords : Biology; Scomberomorus guttatus; Cilacap 


\section{PENDAHULUAN}

Tenggiri papan (Scomberomorus guttatus) adalah ikan yang hidup di permukaan perairan (epipelagic), cenderung bermigrasi lokal, terutama di daerah pantai. Daerah penyebarannya pada kedalaman antara 15-200 $\mathrm{m}$ dan kadang-kadang terdapat di perairan estuari. Ikan ini bermigrasi terbatas tidak seperti jenis ikan tenggiri lainnya (Zahroman \& Mulyani, 2008). Ikan tenggiri papan sering dijumpai bersama dengan gerombolan ikan sarden, cumi, krustasea dan ikan kecil lainnya, pada fase dewasa lebih cenderung menyendiri sedangkan ikan remaja lebih cenderung membentuk gerombolan kecil dalam melakukan migrasi sepanjang pantai (Abedi, et al., 2011).

Gerombolan ikan ini banyak terdapat diperairan Pasifik sebelah barat sehingga dikenal dengan nama Indo-Pasifik king mackerel dan lebih menyukai perairan dengan salinitas antara 25 - 39\%o (Rashid et al., 2010), dan mempunyai kisaran suhu optimum $28^{\circ}-29^{\circ} \mathrm{C}$ (Widodo, 1989). Ikan ini tersebar di sepanjang pantai Pasifik barat mulai dari Teluk Wakasa, Laut Jepang, perairan Selatan Hongkong sampai Teluk Thailand dan sepanjang Semenanjung Arab dan Iran. Penyebaran Scomberomorus guttatus berpotensi hampir di seluruh pesisir kepulauan Indonesia dari Sabang sampai Merauke (Zarochman, 2012).

Pelabuhan Perikanan Samudera (PPS) Cilacap merupakan salah satu pusat pendaratan ikan tuna dan tuna neritik termasuk tenggiri papan di wilayah selatan Jawa. Produksi perikanan di PPS Cilacap pada tahun 2012 mencapai 16.715 ton dan produksi tenggiri papan tercatat sebesar 250 ton atau 1,5\% dari total hasil tangkapan ikan. Persentase tersebut menurun menjadi $0,4 \%$ pada tahun 2013. Penangkapan ikan tenggiri dilakukan oleh nelayan tradisional dengan alat tangkap jaring insang hanyut (drift gillnet). Jumlah alat tangkap gillnet tahun 2012 sebanyak 202 unit dan tahun 2013 sebanyak 230 unit. Peningkatan jumlah gillnet tidak diikuti dengan peningkatan produksi ikan tenggiri, tetapi terjadi sebaliknya. Pada tahun 2013 produksi ikan tenggiri menurun hingga $80 \%$. Menurut data statistik PPS Cilacap tahun 2012 dan 2013 musim penangkapan tenggiri berlangsung pada bulan September hingga Desember (Anonimus, 2013).

Hasil tangkapan ikan tenggiri dengan alat tangkap gillnet ukurannya cenderung mengecil dan dikhawatirkan akan mengganggu kelestariannya. Untuk itu perlu diteliti aspek biologinya sehingga dapat dilakukan tindakan pengelolaan untuk keberlanjutan usaha penangkapanya. Penelitian ikan tenggiri di perairan selatan Jawa masih terbatas terutama yang terkait dengan aspek biologi.

Penelitian ini membahas secara singkat beberapa hal, meliputi: distribusi ukuran, pola pertumbuhan, Nisbah kelamin dan tingkat kematangan gonad. Hasil penelitian ini diharapkan dapat digunakan sebagai masukan bagi pengelolaan perikanan yang berkelanjutan.

\section{BAHANDANMETODE Waktu dan Lokasi}

Pengumpulan contoh ikan tenggiri papan (Scomberomorus guttatus) dilakukan di Pelabuhan Perikanan Samudera (PPS) Cilacap pada bulan Februari sampai dengan Desember 2013. Pengukuran panjang cagak dan bobot individu dilakukan bulanan terhadap hasil tangkapan jaring insang hanyut (drift gillnet) berukuran mata jaring 3 inchi dengan jumlah contoh ikan sebanyak 2.368 ekor. Pengamatan jenis kelamin dan tingkat kematangan gonad dilakukan pada bulan Februari, Mei, dan September.

\section{Analisis Data \\ Hubungan Panjang-Bobot}

Hubungan panjang-bobot mengikuti hukum kubik, bahwa bobot ikan sebagai pangkat tiga dari panjangnya sesuai dengan persamaan dari Bal \& Rao (1984), yaitu:

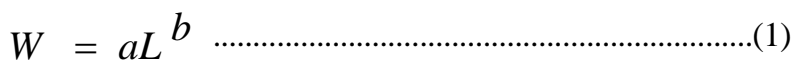

$$
\begin{aligned}
& \log \mathrm{W}=\log \mathrm{a}+\mathrm{b} \log \mathrm{L}
\end{aligned}
$$

Dari persamaan tersebut dapat diketahui pola pertumbuhan ikan yaitu dengan cara melihat nilai b yang diperoleh. Kriteria pola pertumbuhan sesuai dengan Bal \& Rao (1984) sebagai berikut:

a) Jika $\mathrm{b}=3$, pertumbuhan bersifat isometrik, yaitu pertambahan panjang sama dengan pertumbuhan bobotnya,

b) Jika b>3, maka pola pertumbuhan bersifat allometrik positif, yaitu pertambahan bobot lebih cepat dari pertambahan panjangnya,

c) Jika b $<3$, maka pola pertumbuhan bersifat allometrik negatif, yaitu pertambahan panjang lebih cepat dari pertambahan bobotnya.

Untuk mengetahui apakah nilai b yang diperoleh lebih besar, sama dengan atau lebih kecil dari 3 dilakukan uji-t pada selang kepercayaan 95\% (Steel \& Torrie, 1993) dengan hipotesa:

$\mathrm{H}_{0}: b=3$ (isometrik)
$\mathrm{H}_{1}: \mathrm{b} \neq 3$ (alometrik) 
- Jika $\mathrm{t}_{\text {hitung }}$ lebih kecil dari $\mathrm{t}_{\text {tabel }}$ maka $\mathrm{H}_{0}$ diterima dan $\mathrm{H}_{1}$ ditolak.

- Jika $\mathrm{t}_{\text {hitung }}$ lebih besar dari $\mathrm{t}_{\text {tabel }}$ makaH $_{1}$ diterima dan $\mathrm{H}_{0}$ ditolak.

Rumus untuk uji- $\mathrm{t}$ adalah sebagai berikut (Steel \& Torrie, 1993) :

$$
t_{\text {hitung }}=\left|\frac{3-b}{S b}\right|
$$

Untuk memperoleh nilai sb (simpangan baku) dipergunakan persamaan berikut :

$$
\begin{aligned}
& \sum \mathrm{d}^{2} \mathrm{yx}=\sum \mathrm{y}^{2}-\frac{\left(\sum \mathrm{xy}\right)^{2}}{\sum \mathrm{x}^{2}} . \\
& S^{2} y x=\frac{\sum d^{2} y x}{n-2}
\end{aligned}
$$

$S b^{2}=\frac{S^{2} y x}{\sum x^{2}}$

$$
S b=\sqrt{S b^{2}}
$$

Nilai $\mathrm{t}_{\text {tabel }}$ dalam taraf nyata $5 \%(\mathrm{n}-2)$.

\section{Rata-rata Panjang Pertama Kali Tertangkap (Lc50\%) dan Panjang Pertama Kali Matang Gonad (Lm)}

Analisa rata-rata ukuran ikan pertama kali tertangkap (Lc) dilakukan dengan cara membuat grafik hubungan antara panjang ikan (sumbu $\mathrm{X}$ ) dengan jumlah ikan (sumbu Y) sehingga diperoleh kurva berbentuk sigmoid. Nilai Lc yang menggambarkan panjang pada $50 \%$ pertama kali tertangkap dihitung dengan persamaan (Jones, 1976 dalam Sparre \& Venema, 1999) :

$$
S_{L} \text { est }=\frac{1}{1+\exp \left(S_{1}-S_{2} * L\right)}
$$

$\operatorname{Ln}\left[\frac{1}{S L}-1\right]=S_{1}-S_{2} * L$

$$
L_{50 \%}=\frac{S_{1}}{S_{2}}
$$

4) Dimana :

SL = kurva logistik (selektivitas alat tangkap berbasis panjang);

$\mathrm{S}_{1}$ dan $\mathrm{S}_{2}=$ konstanta a dan $\mathrm{b}$ pada rumus kurva logistik

Pendugaan paßjang pertama kali matang gonad ( $\mathrm{Lm}$ ) dilakukan sesuai dengan prosedur penghitungan dari Spearman - Karber yang dilakukan oleh Udupa (1968) dalam Saputra (2005) sebagai berikut :

$\mathrm{m}=\mathrm{X}_{\mathrm{k}}+\mathrm{X} / 2-\left(\mathrm{X} \quad \mathrm{P}_{\mathrm{i}}\right)$

dimana :

$\mathrm{m}$ = logaritma ukuran ikan saat pertama matang gonad

$\mathrm{Xk}=$ logaritma ukuran ikan dimana $100 \%$ ikan sampel sudah matang $\left(\mathrm{P}_{\mathrm{i}}=1\right)$

$\mathrm{X}=$ selisih logaritma ukuran nilai tengah panjang

$\mathrm{P}_{\mathrm{i}}=$ proporsi ikan matang pada kelompok ke-i

Rata-rata ukuran ikan pertama matang gonad diperoleh dari nilai antilog-m.

\section{Tingkat Kematangan Gonad (TKG)}

TKG diamati secara visual dengan cara melihat perubahan morfologi gonad. Perkembangan gonad dibagi menjadi lima stadium berdasarkan Holden \& Raitt (1974) sebagai berikut: 
Tabel 1. Deskripsi tingkat kematangan gonad

Table 1. Description of gonado maturity stages

\begin{tabular}{|c|c|c|}
\hline $\begin{array}{c}\text { Tingkat } \\
\text { Kematangan } \\
\text { Gonad } \\
\text { (Maturity Stage) }\end{array}$ & $\begin{array}{c}\text { Kategori } \\
\text { (Category) }\end{array}$ & Keterangan (Remarks) \\
\hline I & Belum matang/immature & $\begin{array}{l}\text { Ovarium dan testis sekitar } 1 / 3 \text { panjang rongga perut. Ovarium } \\
\text { berwarna merah jambu, transparan, sedangkan testis keputih- } \\
\text { putihan dan telur tidak dapat dilihat dengan mata telanjang. }\end{array}$ \\
\hline II & Perkembangan/maturing virgin & $\begin{array}{l}\text { Ovarium dan testis sekitar } 2 / 3 \text { panjang rongga perut. Ovarium } \\
\text { berwarna merah jambu, jernih dan transparan, sedangkan } \\
\text { testis berwarna keputihan, bentuknya tidak simetris dan telur } \\
\text { tidak dapat dilihat dengan mata telanjang. }\end{array}$ \\
\hline III & Pematangan/ripening & $\begin{array}{l}\text { Ovarium berwarna merah jambu, kekuningan dan terlihat } \\
\text { butiran kecil, sedangkan testis berwarna putih krem dengan } \\
\text { telur transparan dan dapat diamati dengan mata telanjang. }\end{array}$ \\
\hline IV & Bunting/matang/ripe & $\begin{array}{l}\text { Ovarium dan testis sekitar } 2 / 3 \text { sampai memenuhi rongga } \\
\text { perut. Ovarium berwarna coklat kemerahan, banyak diliputi } \\
\text { pembuluh darah dan telur dapat diamati dengan mata } \\
\text { telanjang, sedangkan testis halus dan berwarna putih agak } \\
\text { krem. }\end{array}$ \\
\hline V & Memijah/spent & $\begin{array}{l}\text { Ovarium dan testis berkurang sampai } 1 / 2 \text { panjang rongga } \\
\text { perut. Pada lapisan dinding masih tersisa telur matang, } \\
\text { sedangkan testis bertekstur lembek dan pendek. }\end{array}$ \\
\hline
\end{tabular}

Sumber/source : Holden \& Raitt (1974).

\section{HASIL DAN BAHASAN}

Hasil

\section{Struktur Ukuran Panjang}

Sebaran panjang cagak (fork length) sejumlah 2.368 ekor tenggiri papan (Scomberomorus guttatus) hasil

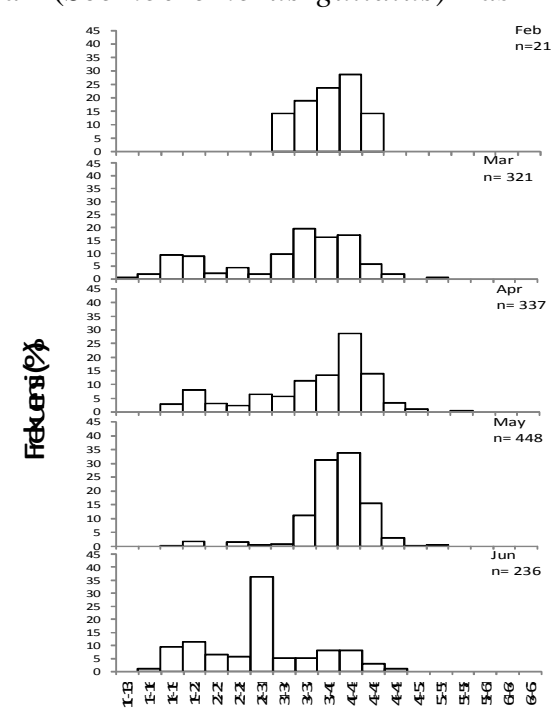

tangkapan gillnet yang dikumpulkan pada bulan Februari -Desember 2013 diperoleh kisaran antara 11,7-66,6 cmFL atau rata-rata $35 \mathrm{cmFL}$ Terdapat ukuran yang dominan pada kisaran panjang antara $40-43 \mathrm{cmFL}$. Distribusi ukuran panjang yang menggambarkan pergeseran modus bulanan dapat dilihat pada gambar 1.

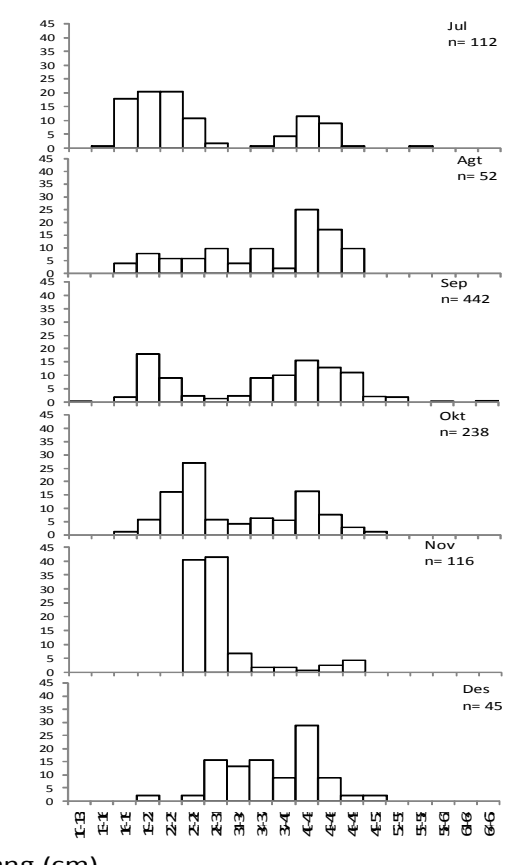

Gambar 1. Distribusi panjang cagak ikan tenggiri papan yang tertangkap gillnet di perairan Cilacap dan sekitarnya pada bulan Februari-Desember 2013.

Figure 1. Fork length distribution of Indo-Pasific King Mackerel caught by gillnet in Cilacap and adjacent waters,February-December 2013. 
Dari gambar 1 tampak bahwa struktur ukuran panjang yang tertangkap cenderung menyebar normal dengan pergeseran modus yang tidak nyata atau relatif sama pada bulan Februari - Juni. Diduga terdapat lebih dari satu kelompok umur (cohort), ditunjukkan oleh jumlah modus lebih dari satu dan adanya pergeseran nilai modus yang nyata pada bulan berikutnya (Juli Nopember).

\section{Hubungan Panjang-Bobot}

Hasil analisis hubungan panjang-bobot ikan tenggiri papan menunjukkan persamaan $\mathrm{W}=0,01 \mathrm{~L}^{3,008}$ dengan nilai koreksi $\left(r^{2}\right)$ sebesar $0,99 \%$ (Gambar 2). Setelah dilakukan uji-t dengan tingkat kepercayaan 95\% (á =0,05) didapatkan pola pertumbuhan bersifat isometrik yang berarti pertambahan panjang sama dengan pertambahan bobotnya.

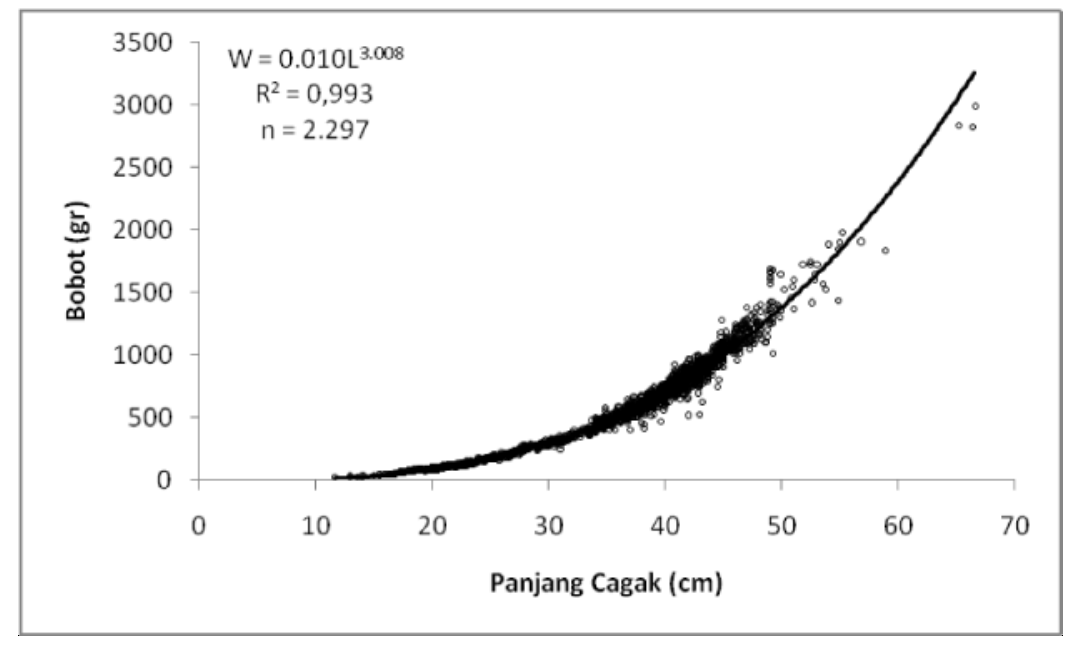

Gambar 2. Hubungan antara panjang cagak dan bobot tenggiri papan (Scomberomorus guttatus).

Figure 2. Length-weight relationship of indo-pacific king mackerel.

\section{Nisbah Kelamin}

Secara keseluruhan, dari 80 ekor ikan tenggiri papan yang tercatat diperoleh hasil 47 ekor ikan jantan dan 33 ekor ikan betina sehingga nisbah kelamin jantan terhadap betina sebagai $1: 0,7$. Nisbah kelamin bulanan ikan jantan terhadap betina ditunjukkan pada Tabel 2. Jumlah ikan tenggiri papan jantan lebih banyak dari dan betina.

Tabel 2. Jumlah sampel dan nisbah kelamin menurut bulan pengamatan.

Table 2. Number of samples and sex ratio by month.

\begin{tabular}{llll}
\hline $\begin{array}{c}\text { Bulan } \\
(\text { month })\end{array}$ & $\begin{array}{l}\text { Jantan (ekor) } \\
(\text { male })\end{array}$ & $\begin{array}{l}\text { Betina (ekor) } \\
\text { (female })\end{array}$ & $\begin{array}{l}\text { Nisbah kelamin } \\
(\text { sex ratio) }\end{array}$ \\
\hline Februari & 14 & 7 & $1: 0,5$ \\
Mei & 22 & 14 & $1: 0,64$ \\
September & 11 & 12 & $1: 1,1$ \\
Jumlah & 47 & 33 & $1: 0,7$ \\
\hline
\end{tabular}

\section{Tingkat Kematangan Gonad (TKG)}

Tingkat kematangan gonad ikan betina dan perubahan morfologi ovarium dan testisnya. Tabel 3 menunjukkan perubahan TKG pada setiap bulan pengamatan. kematangan testis pada ikan jantan diamati berdasarkan

Tabel 3. Persentase tingkat kematangan gonad dan testis ikan tenggiri papan pada bulan Februari, Mei dan September 2013

Table 3. Percentage Maturation of gonads and testes of indo-pacific king mackerel in February, May and September 2013

\begin{tabular}{|c|c|c|c|c|c|c|c|c|c|c|}
\hline \multirow{3}{*}{ Bulan (Month) } & \multicolumn{10}{|c|}{ Tingkat kematangan gonad / Maturity stage (\%) } \\
\hline & \multicolumn{5}{|c|}{ Jantan / Male } & \multicolumn{5}{|c|}{ Betina / Female } \\
\hline & 1 & II & III & IV & V & 1 & ॥ & III & IV & $\mathrm{V}$ \\
\hline Februari & 7,15 & 42,85 & 42,85 & 7,15 & - & $=$ & 28,57 & 28,57 & 42,86 & - \\
\hline Mei & - & 59,1 & 40,9 & - & - & - & 14,3 & 50 & 35,7 & - \\
\hline September & 90,9 & 9,1 & $=$ & $=$ & - & 16,67 & 50 & 16,67 & 16,66 & . \\
\hline
\end{tabular}


Tabel tersebut menunjukkan dominasi TKG IV pada individu jantan dan betina terjadi pada bulan Februari dan Mei. Dugaan awal musim pemijahan terjadi pada akhir bulan Maret dan Juni. Dengan demikian ikan tenggiri papan mempunyai sifat pemijahan yang bertahap (multiple spawner).

\section{Rata-rata Panjang Pertama Kali Tertangkap (Lc) dan Panjang Pertama Kali Matang Gonad (Lm)}

Pendugaan rata-rata ukuran panjang pertama kali tertangkap (Lc) ikan tenggiri papan diperoleh nilai 32,7 cmFL dan rata-rata ukuran panjang pertama kali matang gonad (Lm) adalah 42,34cmFL (Gambar 3).

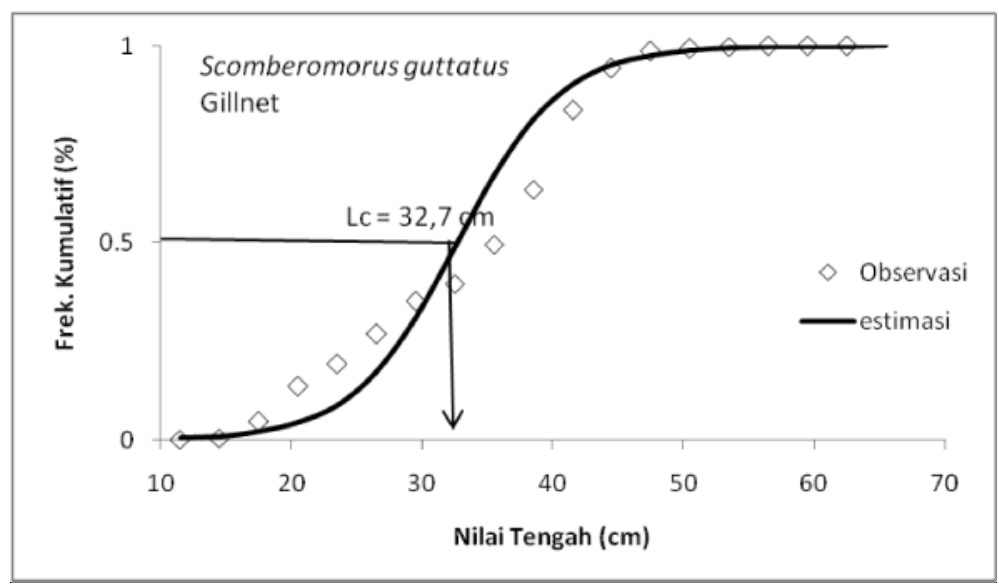

Gambar 3. Panjang rata-rata (50\% kumulatif) ikan tenggiri papan di perairan Cilacap dan sekitarnya.

Figure 3. Average length (50\% cumulatif) of indo-pacific king mackerel in Cilacap and adjacent waters.

\section{Bahasan}

Kisaran panjang ikan tenggiri papan di perairan Cilacap dan sekitarnya yaitu 11,7-66,6 cmFL. Panjang maksimum ikan tenggiri papan di perairan India bagian selatan yaitu 76 cmFL (Collette\&Nauen, 1983). Pada bulan Desember Mei dan Agustus kisaran panjang yang banyak tertangkap berukuran 40-43 cmFL, sedangkan pada bulan Juni-Juli dan September -Desember banyak tertangkap ikan berukuran kecil yaitu pada kisaran panjang 28-31 cmFL dan 19-22 cmFL. Perbedaan ukuran ikan pada setiap bulan menunjukkan adanya pertumbuhan dan rekruitmen baru. Penelitian Rashid et al. (2010) menyebutkan ukuran tenggiri papan yang tertangkap di perairan sebelah tenggara Bangladesh memiliki ukuran antara 25-70 cmTL. Selanjutnya Ahmed, et al.(2014) menyebutkan ukuran ikan tenggiri yang tertangkap di pantai Karachi, Pakistan memiliki ukuran berkisar antara 48-52,3 cmTL. Perbedaan nilai ukuran dari berbagai perairan tersebut disebabkan oleh kebiasaan dan ketersediaan makan, umur, alat tangkap dan kondisi lingkungan.

Analisa hubungan panjang - bobot merupakan salah satu faktor yang perlu diketahui dalam kaitan pengelolaan sumber daya perikanan. Menurut Richter (2007) dan Blackweel (2000), pengukuran panjang- bobot ikan bertujuan untuk mengetahui variasi berat dan panjang ikan secara individual atau kelompok individu, sehingga dapat dijadikan petunjuk mengenai tingkat kegemukan, kesehatan, produktifitas, kondisi fisiologis dan perkembangan gonad. Diperairan Cilacap hasil uji - $t$ terhadap parameter b pada selang kepercayaan $95 \%$ $(a=0,05)$, diperoleh $\mathrm{t}_{\text {hitung }}<\mathrm{t}_{\text {tabel }}$, yang artinya $\mathrm{b}$ sama dengan 3. Dengan demikian maka hubungan panjang bobot memiliki pola pertumbuhan isometrik, dimana pertambahan panjang sama dengan pertambahan beratnya. Hasil sebaliknya diperoleh dari penelitian Rashid et al. (2010) di Teluk Bengal Bangladesh yang menyatakan pola pertumbuhan ikan tenggiri papan bersifat allometrik negatif. Hasil penelitian Devaraj (1981) di Selatan India juga diperoleh pola pertumbuhan ikan tenggiri papan bersifat alometrik negatif. Hasil penelitian Pauly et al. (1996) menyatakan ikan tenggiri papan di perairan barat Indonesia bersifat isometrik dengan nilai $b=3,002$. Hasil-hasil tersebut menunjukkan ikan tenggiri papan di perairan Indonesia dengan di Teluk Bengal hingga Selatan India memiliki perbedaan pola pertumbuhan. Perbedaan pola pertumbuhan tersebut menurut Al-Zibda \& Odat (2007) disebabkan oleh perbedaan kesuburan perairan yang berhubungan dengan ketersediaan makanan. Identifikasi rantai makanan diperlukan untuk memahami ketersediaan pangan dalam habitat alami ikan. Secara umum, konsumsi makanan dari kebanyakan ikan berkorelasi dengan suhu air dan musim pemijahan.

Nisbah kelamin ikan tenggiri papan jantan terhadap betina secara keseluruhan sebagai 1:0,7 yang berarti jumlah tersebut dalam keaadaan tidak seimbang atau individu jantan lebih banyak dari betina. Menurut Effendi (1979) perbandingan jumlah individu jantan dan betina yang seimbang lebih memungkinkan terjadi pembuahan sel telur oleh spermatozoa hingga menjadi individu baru. 
Persentase komposisi TKG pada setiap periode dapat digunakan untuk menduga musim pemijahan (Effendie, 1979). Berdasarkan hasil penelitian, di perairan Cilacap komposisi TKG setiap bulannya yang beragam. Pada ikan tenggiri papan jantan dan betina diperoleh TKG III dan IV yang dominan pada Februari dan Mei sehingga diduga pada bulan Maret dan Juni memasuki masa pemijahan (spent). Dengan demikian maka ikan tenggiri papan mempunyai sifat pemijahan yang bertahap (multiple spawner). Hasil penelitian ini serupa dengan penelitian oleh Devaraj (1987) di teluk Mannar India, dimana pada bulan Maret sampai dengan Mei banyak ditemukan ikan tenggiri papan betina pada stadia III dan IV. Musim pemijahan di teluk Mannar India terjadi pada bulan Febuari sampai dengan Oktober dengan puncaknya terjadi pada bulan Mei sampai dengan Agustus.

Rata-rata ukuran pertama kali tertangkap (Lc50) sebesar 32,7 cmFL dan rata-rat ukuran pertama kali matang gonad (Lm50) sebesar 42,34 cm. Hasil penelitian Devaraj (1987) di Teluk Mannar diperoleh panjang pertama kali matang gonad sebesar $40 \mathrm{~cm}$. Menurut Lagler et al. (1962) dalam Larasati (2011) perbedaan ukuran pertama kali matang gonad dipengaruhi oleh beberapa faktor antara lain kebiasaan makan, umur, ukuran, dan kondisi fisiologis dari ikan tersebut. Pendugaan rata-rata ukuran ikan tenggiri papan pertama kali tertangkap lebih kecil dibandingkan dengan ukuran pertama kali matang gonad (Lc<Lm ;32,7cm <42,34 cm). Hal ini berarti sebelum memijah, ikan sudah tertangkap oleh nelayan. Jika keadaaan ini terus berlangsung dapat mengganggu kelangsungan sumberdaya ikan tenggiri papan secara berkelanjutan.

\section{KESIMPULAN}

Pola pertumbuhan ikan tenggiri papan (Scomberomorus guttatus) di perairan Cilacap dan sekitarnya bersifat isometrik dimana pertambahan panjang sama dengan pertambahan bobotnya. Sebanyak contoh ikan 2.368 ekor diperoleh kisaran panjang ikan antara 11,7 - 66,6 cmFL. Nisbah kelamin ikan jantan terhadap betina sebagai 1:0,7. Individu jantan dan betina matang gonad (stadia IV) banyak terdapat pada bulan Februari dan Mei. Diduga ikan tenggiri papan mempunyai pemijahan bertahap (multiple spawner), dimana memasuki awal pemijahan (spent) pada bulan Maret dan Juni. Rata-rata panjang pertama kali matang gonad yaitu 42,34 cmFL dan ukuran pertama kali tertangkap dengan gillnet yaitu 32,7 cmFL.

\section{PERSANTUNAN}

Tulisan ini merupakan kontribusi dari hasil penelitian aspek biologi, tingkat pemanfaatan dan optimasi pemanfaatan sumberdaya ikan pelagis besar di WPP 572,
573, dan 717 untuk mendukung industrialisasi perikanan, T.A 2013 di Balai Penelitian Perikanan Laut, Jakarta.

\section{DAFTAR PUSTAKA}

Abedi, E., Mohammadi, M., Qasemi, A., \& Mirza, R. (2011). Stock structure of Indo-Pacific King Mackerel (Scomberomorus guttatus) in the Persian Gulf using Microsatellite Loci. World Journal of Fish and Marine Sciences. 3(4), 351-356

Ahmed, Q., Khan, K. \& Yousuf, F. (2014). Length-weight relationship in adult Scomberomorus guttatus (Bloch \& Scheider, 1801) from Karachi coast, Pakistan. International Journal of Biological Research. 2(2), 101-107.

Al-Zibdah ,M. \& Odat, N. (2007). Fishery status, growth, reproduction biology and feeding habit of two scombrid fish from the Gulf of Aqaba Red Sea. Lebanon Science Journal. Vol. 8, No.2, 3-16

Anonimus. (2013). Statistik Pelabuhan Perikanan Samudera Cilacap. Jakarta : Direktorat Jenderal Perikanan Tangkap Kementerian Kelautan dan Perikanan.

Bal, D.V.\& Rao, K.V. (1984). Marine Fisheries (p. 491). New Delhi : Tata McGraw-Hill Publishing Company.

Blackweel, B.G., Brown M.L. \&Willis D.W. (2000). Relative weight (Wr) status and current use in fisheries assessment and management. Reviews in Fisheries Science(8), 1-44

Collette, B.B. \& Nauen, C.E. (1983). FAO Species Catalogue. Vol. 2. Scombrids of the world. An annotated and illustrated catalogue of tunas, mackerels, bonitos, and related species known to date. Rome : FAO. FAO Fish. Synop 125(2), 137 p.

Devaraj, M. (1981). Age and growth of three species of seerfishes Scomberomorus commerson, S. guttatus and S. lineolatus. Indian Journal Fisheries. Vol.28, 104 127.

Devaraj, M. (1987). Maturity, spawning and fecundity of the spotted seer, Scomberomorusguttatus, in the Gulf of Mannar and Palk Bay. Indian Journal of Fisheries. Vol. 34, 48-77.

Effendie, H. M. I. (1979). Metode Biologi Perikanan (p. 112). Bogor : Yayasan Dewi Sri.

Holden, M. J. \&RaittD. F. S.(Eds.). (1974). Manual of Fisheries Sciences. Part 2. Methods of Resource 
Investigation and Their Application (p. 214). FAO Fish, Tech. Pap.(115). Rev. 1

Larasati, D.A. (2011). Kajian reproduksi biologi ikan kembung perempuan (Rastrelliger brachysoma, Bleeker 1851) di perairan Teluk Jakarta, Jakarta Utara. Skripsi Fakultas Perikanan dan Ilmu Kelautan Institut Pertanian Bogor. Bogor.

Pauly, D., Cabanban A, \&. Torres, F.S.B. (1996). Fishery biology of 40 trawl-caught teleosts ofwestern Indonesia. In Pauly, D \& Martosubroto (Eds): Baseline studies of biodiversity: the fish resource of western Indonesia. ICLARM Studies and Reviews 23, 135-216.

Rashid, Mustafa \& Dewan. (2010). Population dynamics and the management of the Indo-Pacificking mackerel, Scomberomorus guttatus from the upper Bay of Bengal off Bangladesh coast. The Bangladesh Veterinaria. $27(2), 82-90$

Richter, T.J. (2007). Development and evaluation of standard weight equations forbridgelip sucker and large scale sucker. North American Journal of Fisheries Management. 27, 936-939.

Saputra, S.W. (2005). Dinamika populasi udang jari (Metapenaeus elegans de man) dan pengelolaannya di Laguna Segara Anakan Kabupaten Cilacap Jawa Tengah. Disertasi Program Pasca Sarjana Institut Pertanian Bogor. Bogor.

Sparre, P. \& VenemaS. C. (1999). Introduksi pengkajian stok ikan tropis. Badan Penelitian dan Pengembangan Perikanan. Terjemahan dari Introduction to tropical fish stock assessment. FAO Fish Tech. Paper 306(1), $376 \mathrm{p}$.

Steel, R. G. D. \& TorrieH. 1993. Prinsip dan Prosedur Statistika Suatu Pendekatan Biometrik (p. 333). Diterjemahkan oleh Bambang Sumantri. Edisi Kedua. Jakarta : PT. Gramedia Pustaka Utama.

Widodo, J. 1989. Sistematika, biologi, dan perikanan tenggiri (Scomberomorus, Scombridae) di Indonesia. Oseana. Vol. XIV(4), 145-150.

Zahroman\&Mulyani. 2008. Kajian sumberdaya dan usaha penangkapan ikan tenggiri papan di Indonesia. Ariomma. Vol 23.

Zarochman, K. 2012. A Brief review indo-pacific king mackerel (Scomberomorus guttatus) in Indonesia. IOTC-2012-WPNT02-19. 